\title{
A desdita de Cálcis: a primeira experiência monástica de Jerônimo
}

\author{
The Chalcis bad luck: the first Jerome's experience
}

\begin{abstract}
Marcus Cruz*
Resumo: A segunda metade do século IV, na região da bacia do Mar Mediterrâneo, se configurou como um momento particularmente marcado por profundas transformações e conflitos. Dentre as mudanças e enfrentamentos destacamos, por um lado, a ascensão do movimento monástico no seio da comunidade cristã e, por outro, as disputas entres as intelligentsias cristã e pagã em torno do domínio da paideia. Tais questões serão discutidas tendo como ponto de partida e elemento aglutinador a experiência monástica vivenciada por Jerônimo no deserto de Cálcis entre os anos 374 e 377.

Abstract: The second half of the fourth century in the region of the Mediterranean Sea Basin was a time particularly marked by profound transformations and conflicts. Among the changes and confrontations, we highlight on the one hand the rise of the monastic movement within the Christian community and on the other the disputes between the Christian and pagan intelligentsia around the control of the Paideia. These questions will be discussed based on the monastic experience experienced by Jerome in the desert of Chalcis between 374 and 377.
\end{abstract}

\author{
Palavras-chave: \\ Antiguidade Tardia. \\ Paideia. \\ Monacato. \\ Jerônimo.
}

\footnotetext{
* Doutor em História Social pela Universidade Federal do Rio de Janeiro. Professor associado do Departamento de História e do Programa de Pós-Graduação em História da Universidade Federal de Mato Grosso (UFMT).
} 
"Ali contemplaria um deserto mais ameno do que qualquer cidade. Veria lugares desolados cercados, tal como o Paraíso, por um exército de santos" (Jerônimo, Epistolae, XIV, 10). As pungentes palavras de Jerônimo presentes em sua epístola destinada a Teodósio demonstram a profunda admiração que o nosso autor dedica à opção de vida cristã de cunho monástico.

É verdade que o Estridonense não era o único habitante da bacia do Mar Mediterrâneo que, neste momento, no caso, as últimas décadas do IV século da Era Comum, estava tomado de um intenso e arraigado entusiasmo pela perspectiva de vida monástica. As práticas ascéticas, a renúncia aos bens materiais e o abandono do mundo cultivado pelos monges assumiram, neste tempo, a condição de um dos caminhos dos cristãos para a glória eterna, e possivelmente tenha sido percebido, por muitos fiéis, como o mais apropriado dos itinerários rumo à salvação, numa época em que a busca pela vida eterna assume uma importância capital como já nos ensinou Henri-Irénée Marrou (1980, p. 51):

\footnotetext{
Se agora contemplarmos as coisas, não partindo de Deus, senão desde o ponto de vista do homem, esta nova religiosidade se caracteriza pela recente importância ligada ao além, à vida além-túmulo, à vida eterna: fé nessa vida, esperança de que será feliz, ansiosa preocupação por obtê-la como tal - como salvação. É significativo que a palavra salus, originalmente usada nesta língua de camponeses, solidamente apegados às realidades mais concretas, que eram os antigos romanos, para designar pura e simplesmente a saúde física, se converteu, sob a pena dos escritores cristãos, no termo para designar a salvação eterna.
}

Por seu turno, não podemos e nem devemos esquecer que os trabalhos de Peter Brown revelaram a importância que os monges assumiram na sociedade tardo-antiga, como uma das principais encarnações e manifestações do homem santo, aquele ser que, pelo seu estilo de vida, ascende à condição de homem de poder, que atinge a parrhesia, que consegue dobrar a vontade do Senhor dos Céus, como também dos senhores temporais, tornando-se um patronus (BROWN, 1972, p. 101-108; CANER, 2002, p. 5).

A importância e o enraizamento do movimento monástico na realidade da Antiguidade Tardia se apresentam como um fenômeno incontestável e sobre o qual é sempre necessário nos debruçarmos, no sentido de compreender de forma mais atilada este momento do devir histórico. Nessa perspectiva, o problema a ser colocado, nesta oportunidade, é discutir a primeira experiência monacal de Jerônimo, qual seja, aquela vivenciada por ele no deserto de Cálcis, na província da Síria, entre os anos de 374 e 377.

Neste período, o Estridonense escreveu quinze epistolas que foram conservadas e que, portanto, chegaram até os tempos atuais em diversas edições. Essas missivas serão o corpus documental a partir do qual empreenderemos a análise que busca inserir a 
experiência ascética inicial de Jerônimo no contexto das correntes monásticas existentes na sociedade tardo-antiga, assim como explicar porque, apesar de seu entusiasmo pela vida monacal, nosso autor não foi capaz de permanecer no deserto, uma vez que essa primeira experiência monástica jeronimiana durou cerca de três anos apenas.

Nossa hipótese para a questão proposta se articula com uma das grandes problemáticas que atravessam a Antiguidade Tardia, qual seja, o conflito entre os intelectuais pagãos e cristãos pela apropriação do legado, da herança, da paideía. Em outras palavras, a primeira experiência monástica levada a cabo por Jerônimo, tanto pelo estilo de vida adotado, quanto pelo isolamento imposto pela solidão do intermúndio, acabou por se chocar com a formação intelectual de nosso autor. O Estrodinense esperava encontrar, no deserto de Cálcis, um local onde pudesse vivenciar o ideal ascético aliado aos estudos. A realidade se mostrou muito diferente do esperado.

A discussão proposta necessariamente precisa embrenhar-se por certos pontos inescapáveis, tais como o universo cultural tardo-antigo, bem como a emergência do movimento monástico na sociedade romana e, finalmente, a análise da experiência monacal jeronimiana. O ponto de partida escolhido é expor, de forma sintética, as questões relativas ao universo cultural da sociedade romana da Antiguidade Tardia.

\section{A 'paideia' romano-helenística como universo cultural tardo-romano}

É oportuno e crucial iniciar o debate proposto apresentando duas definições fulcrais para o desenvolvimento da argumentação, a saber: o que se entende por universo cultural, por um lado, e, por paideia, por outro. Ambos são conceitos de grande complexidade e que apresentam uma fortuna crítica extensa e diversificada, especialmente no que tange às argumentações em torno da ideia de cultura. Adentrar de forma profunda no campo dessa peleja não está no escopo deste trabalho, portanto o que faremos é apresentar a perspectiva conceitual que norteia a presente investigação.

Nesse sentido, no que concerne à concepção de universo cultural, esta encontrase alicerçada, principalmente, nas ideias de Clifford Geertz (1989, p. 15) quando este afirma: "acreditando, como Max Weber, que o homem é um animal amarrado a teias de significados que ele mesmo teceu, assumo a cultura como sendo essas teias [...]". Portanto, a partir dessa perspectiva conceitual, o universo cultural é compreendido como essa rede simbólica, uma estrutura de sentidos construída pelos homens no devir histórico e sujeita às vicissitudes do tempo, na qual as ações humanas e os acontecimentos sociais são constante e continuamente significados e resignificados. 
Nesse sentido, se estabelece entre universo cultural e as ações humanas uma relação que é basilar. Tal nexo é entendido a partir do que Marshall Sahlins denomina de estrutura da conjuntura. Com este conceito, o antropólogo norte-americano pretende elaborar um instrumental analítico capaz de entender a articulação existente entre a continuidade e a mudança, entre passado e presente, entre teoria e práxis, no bojo tanto de determinado universo cultural e simbólico quanto de uma sociedade específica. Nas palavras do autor:

Desse modo é que a 'estrutura da conjuntura' entra aqui: na sociologia de situação das categorias culturais com as motivações que oferece aos riscos de referência e às inovações de sentido. Uma prática antropológica total, contrastando com qualquer redução fenomenológica, não pode omitir que a síntese exata do passado e do presente é relativa à ordem cultural, do modo como se manifesta em uma estrutura da conjuntura específica (SAHLINS, 1990, p. 190).

O esforço intelectual de Sahlins busca compreender tanto a interação entre uma cultura, entendida como uma teia simbólica, e as ações e acontecimentos que encontram seus significados nesta rede de símbolos, bem como o processo de transformação desta estrutura, no qual os eventos podem tanto assumir um papel de elementos de reforço do universo simbólico quanto de mudança desta ordem cultural. Citando mais uma vez o antropólogo norte-americano:

\footnotetext{
Mais ainda, o caso havaiano já nos mostrou, mesmo com toda a sua historicização dos mundos, que não há base alguma nem razão para a oposição excludente entre estabilidade e mudança. Todo uso efetivo das ideias culturais é em parte reprodução das mesmas, mas qualquer uma dessas referências também é, em parte, uma diferença (SAHLINS, 1990, p. 190).
}

As ideias de Marshall Sahlins são de extrema fecundidade para pensar as questões relativas ao universo cultural tardo-antigo, no qual se observava o estabelecimento lento, e não isento de recuos, de uma hegemonia da intelectualidade cristã que se avoca como a única e legítima herdeira da paideía. Portanto, a estrutura simbólica existente na Antiguidade Tardia experimentou inequívocas transformações. No entanto, tais mudanças não significaram o abandono total e absoluto das significações existentes, pois, como já afirmou Sausurre (1970, p. 74): "aquilo que predomina em toda mudança é a persistência da substância antiga: a desconsideração que se tem pelo passado é apenas relativa. É por esta razão que o princípio da mudança se baseia no princípio da continuidade".

O universo cultural das elites na Antiguidade Tardia, que se encontrava em um processo de mudanças, era profundo e claramente articulado em torno da paideia que se constituía como elemento articulador a partir do qual essa teia simbólica se conectava. 
O conceito de paideia, desta maneira, é a segunda noção que será necessariamente discutida no presente item.

A palavra $\pi \alpha \iota \delta \varepsilon i ́ \alpha$, na língua grega, encontrava-se profunda e intrinsecamente ligada à ideia de educação, entendida como uma formação do homem em um sentido bastante amplo, nas palavras de Silvana Bollis (2013, p. 50):

[A Paideía] busca formar o homem em sua integralidade, corpo, alma, sensibilidade e racionalidade, formando-lhe o caráter, espiritual, à medida que busca permanentemente a justiça usando o critério da verdade. Não apresenta caráter utilitarista ou pragmático, pois não busca adestrar ou instrumentalizar o indivíduo no exercício de "fazer algo" e sim, uma formação plena que tem o homem e suas formas de "con-viver" em sociedade como principal objeto do seu pensar.

Nesse sentido, portanto, é preciso lembrar que o termo paideia não se configura como um simples vocábulo, como uma singela palavra. Paideía é um conceito que abarca uma realidade muito mais vasta do que a educação ou a formação do cidadão e do homem.

Na sua monumental obra, Paidéia: os ideais da cultura grega, Werner Jaeger buscou entender as relações estabelecidas entre paideia, cultura e tradição, uma vez que o autor identificou a noção de paideia com o conceito de cultura: "E na forma de Paideia, de 'cultura', consideraram os gregos a totalidade da sua obra criadora em relação aos outros povos da Antiguidade da qual foram herdeiros" (JAEGER, 1987, p. 6). Ou, ainda, nesta outra passagem: "Porém, os verdadeiros representantes da paideia grega não são os artistas mudos - escultores, pintores, arquitetos -, senão os poetas e músicos, os filósofos, os retóricos. Ou seja, os homens de estado" (JAEGER, 1987, p. 14-15).

As passagens citadas acima mostram que, para o filólogo alemão, a noção de paideia encontra-se profundamente imbricada com o conceito de cultura, constituindo um dos universos simbólicos nos quais os homens do mundo antigo estavam inseridos. É nesse sentido que o conceito é usado nesta investigação, isto é, como o universo cultural, a rede simbólica na qual uma parcela dos habitantes na bacia do Mar Mediterrâneo durante a Antiguidade Tardia, especialmente aqueles que compunham a elite, buscaram conferir significados aos seus atos e ações.

Um ato, uma ação que os homens e mulheres que viviam no espaço mediterrânico tardo-antigo passaram a praticar com uma frequência cada vez maior, foi a opção por viver uma vida ascética e retirada das vicissitudes mundanas. Esse comportamento estava nos primórdios do movimento monástico, que conquistou corações e mentes dos romanos neste período, inclusive Jerônimo, autor das epístolas que serão analisadas. Cabe, então, abordar algumas facetas do impulso monacal na Antiguidade Tardia. 


\section{Apontamentos sobre o movimento monástico tardo-antigo}

A eclosão, no Oriente mediterrânico, do movimento monástico, bem como o seu expressivo desenvolvimento ao longo dos séculos IV e $\mathrm{V}$ em torno da bacia deste mar, se constituiu como um dos principais fenômenos tanto da história do cristianismo como da história da sociedade tardo-romana. Nas palavras de David Caner (2009, p. 588): "o monasticismo cristão foi uma invenção da Antiguidade Tardia, e a última grande experiência social a surgir no mundo mediterrâneo antigo".

A perspectiva proposta pelo professor da Universidade de Indiana se apresenta como bastante profícua, na medida em que contempla o monacato como um fenômeno não somente religioso, mas também social, mesma perspectiva analítica defendida por Samuel Rubenson (2007, p. 637): "[...] a emergência do monasticismo constitui uma mudança social, política e na cultura religiosa surpreendentemente rápida e radical". Tal abordagem também permite refletir de forma diferenciada acerca das origens do movimento monástico, na medida em que este está inserido e articulado ao um contexto histórico.

A concepção relativa aos primórdios do monasticismo cristão, longamente sedimentada na historiografia que se dedica aos estudos da História da Igreja, afirma, de forma peremptória, que a vida monacal surge no Egito do século III da Era Comum, tendo em Antão uma figura central nesse processo (HERTLING, 1984, p. 111-120; LENZENWEGER, 2006, p. 76-79; MARAVAL, 2009, p. 97-101; JEDIN, 1980, p. 457-465; LABRIOLLE, 1936, p. 299-303). Obras dedicadas à investigação da história do monacato também compartilham, de forma majoritária, da concepção das origens egípcias da experiência monástica cristã (MASSOLIVER, 1994, p. 37; GOBRY, 1985, p. 147-161; COLUMBAS, 1974-75, p. 45-50; WIPSZYCKA, 2011, p. 162-163; ROUSSEAU, 2010, p. 11).

Essa perspectiva analítica precisa ser matizada, ainda que não descartada, em sua totalidade. Por um lado, é correto afirmar que, a partir do século III da Era Comum, ocorre a organização e a instituição de certas formas de vida monacal, ainda que não de maneira teleológica e providencial, que encontramos na literatura monástica do período. Por outro lado, é necessário reconhecer que o movimento monástico possui antecedentes tanto no âmbito do próprio cristianismo, seja em sua dimensão ortodoxa, seja em suas vertentes heréticas, como também é possível identificar práticas características dos monges em ambientes não-cristãos.

Além dessas raízes apostólicas, podemos encontrar a presença de elementos constitutivos do movimento monástico em outras experiências sociais, culturais ou religiosas próprias do mundo mediterrâneo antigo. É o caso, por exemplo, dos essênios 
dentro da tradição judaica, com seu afastamento do mundo e suas práticas ascéticas (MASSOLIVER, 1994, p. 21-22). Ou ainda dos encratistas, que consideravam a castidade como a virtude cristã por excelência e, assim sendo, condenavam o casamento (FINN, 2009, p. 69-71). Concepção compartilhada, no mesmo momento, pelos gnósticos e marcionistas, que também consideravam o corpo a origem de todo o mal humano (MUEHLBERGER, 2008, p. 452)

No entanto, queremos chamar a atenção para a confluência entre as práticas e o princípio do monacato e de certa tradição filosófica pagã. Aquela em que a:

Filosofia era entendida [nessa tradição] primariamente como a busca e aprendizado da vida perfeita, pré-condição para o conhecimento e a iluminação divina. Uma vida filosófica era da mesma maneira uma vida não apenas dedicada às atividades intelectuais, mas também um distanciamento dos assuntos sociais e políticos, bem como a libertação dos prazeres da riqueza e do corpo (RUBENSON, 2007, p. 639).

Não devemos esquecer que, no bojo da paideia, a vida contemplativa e afastada do mundo era considerada como summum bonum humanum (CANER, 2009, p. 594).

Perceber as ligações entre o movimento monástico e as concepções filosóficas que circulavam pelo universo cultural tardo-antigo é duplamente importante nesta oportunidade. Uma vez que, por um lado, reforça a perspectiva analítica que adotamos, segundo a qual a paideia se configurava como uma das redes simbólicas da sociedade romana baixo imperial, especialmente no que concerne às elites, sem esquecer que essa teia de significados, usando a nomenclatura de Geertz (1989), encontrava-se, nesse momento, no centro de uma acirrada disputa entre os grupos cristãos e pagãos pelo controle e hegemonia dessa estrutura cultural.

Por outro lado, essa convergência também corrobora nossa hipótese para explicar o fracasso da primeira tentativa de vida monacal jeronimiana. Em outras palavras, Jerônimo esperava encontrar, em Cálcis, uma vida ascética, mas dedicada à busca do conhecimento e da salvação e, talvez pudéssemos nos arriscar a dizer, uma vida filosófica cristã. Uma vida que conciliasse a sua formação intelectual com seus anseios espirituais. Porém, não foi a realidade com que se deparou nos confins do deserto sírio. É o momento de traçarmos, rapidamente, a trajetória do nosso autor até o deserto de Cálcis.

\section{Antes de Cálcis}

Jerônimo nasceu em meados do século IV, entre os anos de 340-350 (CAVALLERA, 1922, p. 3-12; PENNA, 1952, p. 9), na cidade de Stridon, como ele mesmo afirmou: "Jerônimo, 
filho de Eusébio, nasceu na cidade Stridon, que foi aniquilada pelos godos e serviu um dia de fronteira entre a Dalmácia e a Panônia" (Jeronimo, De Viris Illustribus, 135)

Jerônimo era oriundo de uma família pertencente à aristocracia provincial, detentora de terras, como podemos perceber nessa breve menção que encontramos na Epístola LXVI, endereçada a Pamáquio: "[...] por isso fui obrigado a mandar meu irmão Pauliniano à minha terra para vender umas vilas meio destruídas, relíquias de nossos pais, que escaparam das mãos dos bárbaros [...]" (Jer., Ep., LXVI, 14). O trecho da carta não apenas nos informa que o círculo familiar do tradutor das Escrituras tinha propriedades agrícolas, ainda que não saibamos exatamente a extensão desses domínios, mas cujos rendimentos foram suficientes para manter e custear os estudos de Jerônimo em Roma, o que nos permite afirmar, portanto, que eram herdades de razoável monta.

Além de estar inserida na aristocracia provincial romana, a linhagem jeronimiana professava o cristianismo: "nós nem criamos dissenções na Igreja nem nos apartamos da comunhão com nossos pais quando desde o berço, por assim dizer, fomos criados no leite católico" (Jer., Ep., LXXXII, 2). Nessa passagem, Jerônimo afirma ser católico desde o nascimento, por conseguinte, oriundo de uma família cristã.

Continuando as considerações biográficas acerca do nosso autor, podemos afirmar que sua infância transcorreu nos moldes de uma criança aristocrática romana, isto é, iniciou seus estudos em uma escola provincial (ANTIN, 1951, p. 11; STEIMANN, 1958, p. 15), onde aprendeu a ler, a escrever e a contar. Como demonstrou aptidão para os estudos, foi enviado à Roma com o intuito de prosseguir sua formação intelectual.

Nesta nova fase de sua vida, particularmente importante para a hipótese apresentada, Jerônimo se empenhou em uma busca incessante de conhecimento, e encontrou, na própria Roma, a sua primeira grande mestra, pois, nela, congregavam-se todos os povos, tradições e culturas do mundo conhecido.

O período de estudos de Jerônimo em Roma estendeu-se, provavelmente, ao longo da década de 360. Tendo estudado gramática com um dos maiores, senão o maior, mestre daquele momento, Élio Donato, que introduziu nosso autor não apenas nos meandros e sutilezas da ars grammatica, mas o fez por meio da leitura e análise dos mais importantes autores latinos da paideia, qual seja, Virgílio, Salústio, Cícero, Terêncio, Plauto, Lucrécio, Horácio (REBENICH, 2002, p. 3).

Os estudos de retórica foram conduzidos pelo não menos célebre Mário Vitorino. Jerônimo se dedicou com afinco ao estudo das obras dos autores latinos, principalmente de Sêneca e Quintiliano. Além dos estudos gramáticos e retóricos, a formação jeronimiana tinha espaço para lições de grego e filosofia (REBENICH, 2002, p. 3). 
É importante destacar que foi em Roma que Jerônimo foi batizado (ANTIN, 1951, p. 35). O interesse deste acontecimento se configura no sentido de que, no mesmo momento em que mergulhou nos estudos nos quais a tradição cultural clássica se mostra como fundamental, o nosso autor decidiu reforçar o seu caráter e sua condição de cristão. Vemos assim reforçada a dualidade, ou melhor, a tensão entre a perspectiva pagã e a cristã no bojo da paideia que marcava tanto a sociedade tardo-antiga quanto a personalidade do nosso autor, tanto o macrocosmo quanto o microcosmo.

Em data incerta, Jerônimo deixou Roma para iniciar uma série de viagens que o levou às Gálias, à sua terra natal e finalmente ao Oriente romano, mais especificamente à cidade de Antioquia, na província da Síria, última etapa antes da decisão de se tornar monge e se dirigir ao deserto de Cálcis. Dessa fase de intensa movimentação, devemos destacar o período vivido na cidade de Aquileia. O Estridonense tem então a oportunidade de compartilhar uma vida ascética comum com um grupo de intelectuais que se dedicavam aos estudos, o que configura uma experiência de cunho monástico, ainda que Jerônimo não considere esse período de sua vida da mesma maneira (KELLY, 1975, p. 25-33).

É o momento de nos debruçarmos sobre o período em que nosso autor viveu no deserto de Cálcis e procurar entender e explicar o fracasso dessa experiência monástica jeronimiana.

\section{A experiência monástica de Jerônimo em Cálcis}

Datam do período vivido em Cálcis um conjunto de 15 epístolas, as de número 3 a 17, na coleção publicada pela Biblioteca de Autores Cristãos. Essas missivas tiveram 15 destinatários diferentes, sendo que dois deles, Rufino e Dâmaso, receberam duas cartas do Estridonense. Duas cartas possuem destinatário "coletivos": a Epístola VII, enviada a Cromâncio, Jovino e Eusébio, e a Epístola XI, remetida às Virgens de Hemona.

A primeira carta, escrita após a opção de Jerônimo pela vida monástica, foi dirigida ao amigo e futuro adversário em ácidas polêmicas, Rufino. Nesta epístola, além de algumas notícias pessoais, nosso autor se dedica, principalmente, a discorrer e enaltecer a decisão do amigo em comum, Bonoso, de se tornar monge. O Estridonense demonstra um grande entusiasmo pela escolha do antigo companheiro. Podemos ler o seguinte na missiva em tela:

Um jovem que se formou conosco nas artes liberais do século, dono de grandes riquezas, respeitado entre os seus pares, repudia a sua mãe, as suas irmãs e um irmão queridíssimo e vai viver, como um novo morador do Paraíso, numa ilhota, um obstáculo aos navios em alto-mar que a rodeia, espantosa por seus ásperos penhascos, pelas rochas desnudas e total solidão [...] Ele, tranquilo, intrépido e 
armado a rigor como manda o Apóstolo, agora vê Deus quando estuda os Livros Sagrados, agora fala com Deus quando ora ao Senhor [...]. Goza ele da coroa da virtude e ricamente vestido segue o Cordeiro como prêmio de seus martírios diários (Jer., Ep., III, 4-5).

É mais do que evidente a alacridade presente nas palavras de Jerônimo. A decisão do amigo Bonoso de se dedicar à vida monástica é garantia da salvação dele, o que o faz ter um contato direto com a divindade. A vida monacal é, para o nosso autor, o principal, ainda que não único, caminho dos cristãos em busca da vida eterna.

O entusiasmo pela vida monástica é claramente perceptível em outra carta escrita no período vivido em Cálcis, no caso a Epístola XIV, na qual Jerônimo procura exortar o amigo Heliodoro a abraçar a vida monacal e não o episcopado. Para tanto, o Estridosense lança mão de uma linguagem poderosamente marcada por elementos retóricos:

Oh deserto em que brotam as flores de Cristo! Oh solidão em que se criam aquelas pedras de que, no Apocalipse, se constrói a cidade do grande rei! Oh ermo que goza da familiaridade de Deus! O que fazeis, irmão, no século, tu que eres maior que o mundo? Até quando te irão de oprimir as sombras de teto? Até quando te encerrará o cárcere enfumaçado das cidades? (Jer., Ep., XIV, 10).

Além da contundente súplica para que Heliodoro enverede pelos caminhos monásticos, Jerônimo retoma um importante e central tópos da literatura monacal tardoantiga, qual seja, o tema do deserto e da solidão como o lócus por excelência da vida do monge e, por conseguinte, de convívio com a divindade. Apesar do forte tom retórico das palavras do nosso autor, não é possível outra hermenêutica do trecho citado acima do que afirmar que, para ele, o deserto e, por conseguinte, a solidão é um espaço e uma prática que permitem aos cristãos estarem em contato direto com Deus, criando as condições, senão ideais, pelo menos privilegiadas, para a conquista da salvação.

Nesse sentido, o fracasso de Jerônimo em permanecer no deserto de Cálcis está manifestadamente em contradição com as ideias por ele propugnadas. Mesmo sendo o deserto o local onde as flores de Cristo brotam, gozando da familiaridade com Deus, o Estridonsense não apenas não suportou viver nesse lugar por mais de escassos três anos, como o veremos queixar-se e protestar contra a solidão.

A temática da solidão aparece com destaque nas epístolas jeroniomianas redigidas durante o período vivido no deserto de Cálcis. Vejamos um exemplo: "a solidão em que me encontro não me permite fazer o que mandas" (Jer., Ep., V, 3). Esta é uma missiva endereçada a Florentino e o assunto ao qual o nosso autor se dedica nessa seção do texto diz respeito a um jovem escravo, ou liberto, em fuga. Apesar da condição de solitário estar intrinsicamente inserida na condição monástica, como o próprio Jerônimo não 
apenas sabe, mas também propala, ainda assim a solidão e, por conseguinte, o deserto, aparecem, na passagem citada, como um impeditivo, um obstáculo. Não no sentido de um óbice espiritual, como as tentações vivenciadas pelos monges que, na realidade, são provas que os permitem demonstrar sua fé. No caso apresentado pela passagem, o que é perceptível é que a solidão e, por tabela, o deserto haviam se tornado um entrave, um estorvo que lhe obsta atender ao pedido de um amigo.

Ainda mais sintomática da tensão e da contradição entre o pensamento e a práxis de Jerênimo em relação à solidão são outras passagens do seu epistolário produzido no período estudado. Na Epístola VIII, dirigida a Nícias, subdiácono de Aquileia, podemos ler: "grande alívio terá minha solidão se recebo umas cartas de meus amigos, mesmo que sejam zangadas". Nesse caso, a amizade se torna uma espécie de antídoto contra a solidão e o isolamento vivido. Interpretamos essas palavras do nosso autor, mesmo sem esquecer que o Estridonense é um mestre da retórica, como um indício do desalento e de certa decepção com a vida monacal encontrada em Cálcis.

Essa interpretação é corroborada por uma passagem um tanto ou quanto longa, mas que merece ser citada em sua integra:

\begin{abstract}
A verdade é que quando me trouxe, o varão Evágrio, a esta parte do deserto nos amplos extremos entre os sírios e os sarracenos, minha felicidade foi tal que superou a alegria de Roma no dia em que se anunciou, pela primeira vez depois de Canas, derrotado, por Marcelo junto a Nola, os soberbos exércitos de Aníbal. E ainda que citado irmão me visite com frequência e me queira como a suas próprias entranhas em Cristo, está separado de mim por tão larga distancia que não me deixa em menor solidão ao ir que alegria que traz quando vem.

Agora falo com sua carta, a abraço, ela fala comigo, somente ela aqui sabe latim. Porque aqui ou se tem que aprender uma língua bárbara ou se calar (Jer., $E p_{\text {, }}$ VII, 1-2).
\end{abstract}

O trecho nos parece bastante revelador do processo vivenciado por Jerônimo ao longo de sua estadia em Cálcis. Em primeiro lugar, o entusiasmo inicial pela vida monástica se transformou paulatinamente em desalento devido à solidão e, principalmente, à rusticidade da região e dos companheiros monges. Para alguém que recebeu sua formação nos moldes e parâmetros da paideia, a opção de viver isolado no meio do deserto afastado dos amigos, dos debates intelectuais e, principalmente, cercado por uma rusticidade, por uma barbárie que um homem da paideia rejeita e deprecia, mesmo que essa rusticidade e barbárie venham de cristãos, mesmo que venham de monges.

Essa ideia de que o deserto de Cálcis é um lugar rústico, bárbaro, aparece em outros momentos das missivas jeronimianas escritas entre 374 e 377 . Vejamos alguns exemplos. O primeiro advém da Epístola XV, dirigida a Dâmaso, bispo de Roma: "pelos mesmos pecados emigrei a este deserto que separa a Síria dos confins da barbárie 
[..]" (Jer., Ep., XV, 2). Outra passagem que pode ser citada está em outra carta, também endereçada a Dâmaso: "[...] eu recebi meus trajes de Cristo na cidade de Roma e agora estou encerrado entre a fronteira bárbara com a Síria." (Jer., Ep., XVI, 2). Esses dois trechos de cartas dirigidas ao bispo de Roma não deixam dúvida de que o deserto de Cálcis era, para Jerônimo, um local selvagem, incivilizado, principalmente se comparado à cidade de Roma, cerne e âmago da cultura, da civilização, da paideia.

O melhor exemplo da opinião jeronimiana sobre Cálcis, porém, está na Epístola XVII, última missiva escrita no deserto da Síria e endereçada a Marco:

$E$, primeiramente, antes de falar da minha fé, que conheces perfeitamente, não tenho outro remédio do que clamar contra a barbárie deste lugar com versos que correm: 'Que raça é esta de homens ou que pátria que consente tão bárbaro costume? Se nos impedem o desembarque na praia e entre gritos de guerra não nos deixam colocar o pé na areia (Virgílio, Aeneid, I, 539). Passagem que tomei do poeta gentil, para ver se aqueles que guardam a paz de Cristo aprendem de um pagão (Jer., Ep., XVII, 2).

O trecho citado acima é emblemático para nossa discussão, na medida em que não apenas o deserto de Cálcis aparece mais uma vez como um lugar bárbaro, mas também os habitantes do local, ou seja, os cristãos, ou melhor, os monges. Não deve passar desapercebido que Jerônimo se utiliza de um autor pagão, aquele que era considerado o maior poeta latino de todos os tempos, ou seja, Virgílio, para admoestar seus companheiros de deserto. Essa escolha se apresenta para nós extremamente significativa. Entendemos que ela nos remete diretamente ao âmago de nossa hipótese para compreender o "fracasso" da primeira experiência monástica jeronimiana. A formação intelectual realizada e forjada dentro dos parâmetros e ideais da paideia era incompatível, senão com a vida monacal, pelo menos com o estilo de existência propugnado nas profundezas do deserto de Cálcis. Este conflito se torna insuperável, levando ao desdobramento que se configurava como cada vez mais inevitável.

O ponto de ruptura que levou ao abandono do deserto de Cálcis e, por conseguinte, ao "malogro" dessa primeira experiência monástica jeronimiana, teve como elemento central questões de ordem doutrinal e dogmática, qual seja, as discussões em torno da Trindade, que se desdobraram neste momento no chamado Cisma de Antioquia (FLICHE; MARTIN, 1936, p. 265-266; SILVA, 2014, p. 133-136), no qual a cadeira episcopal foi intensamente disputada.

Isso levará Jerônimo a recorrer a Dâmaso, que naquele momento era bispo de Roma (MCLYNN, 2012, p. 305-325), buscando orientação dogmática e teológica acerca 
das discussões que incendiavam Antioquia e que importunavam e desestabilizavam o nosso autor. Jerônimo se dirige dessa forma ao sucessor de Pedro, na Epístola XVI:

\begin{abstract}
Assim, meu inimigo incansável me segue, de sorte que agora na solidão a mais cruel guerra. De um lado aumenta o furor ariano sustentado pelos poderes do mundo; de outro, a Igreja está dividida em três facções e cada uma se empenha em me atrair. A antiga autoridade dos monges que moram no entorno se levanta conta mim. Eu, entretanto, não cesso de dizer: 'O que determinar a Cátedra de Pedro é o meu'[...] Por isso invoco sua beatitude pela Cruz do Senhor, por sua Paixão, honra essencial de nossa fé[...]que me indique com tuas letras com quem devo estar em comunhão aqui na Síria.
\end{abstract}

A passagem é de uma uberdade significativa. Podemos ressaltar que, mais uma vez, Jerônimo retoma a temática da solidão agravada pelos conflitos doutrinais em torno da Trindade. É interessante e, em certo sentido, um tanto paradoxal que, nesse momento, essa soledade se encontre por demais movimentada devido às cobranças dos monges sírios acerca do posicionamento do Estridonense na polêmica que esgarça a igreja antioquena. Ou seja, parece que nosso autor está vivendo um isolamento bastante povoado. As inventivas anteriores contra a solidão, clamando por companhia quando atendidas, não satisfazem Jerônimo porque tanto ocorrem no seio de uma disputa que contribuiu para aumentar a insatisfação com o ambiente monástico de Cálcis quanto pela razão de os monges sírios não compartilharem a paideia e, portanto, não serem os interlocutores que o Estridonense desejava. Tais elementos acabaram amalgamando-se e tornando-se o motivo final que levou ao abandono do deserto por nosso autor.

O trecho também nos permite corroborar duas informações presentes na historiografia acerca do Cisma de Antioquia, quais sejam, de que havia três facções em disputa pelo controle da cátedra episcopal e, por conseguinte, da liderança da comunidade antioquena, assim como a intervenção do poder imperial no litígio.

Finalmente, ainda sobre esse fecundo fragmento do epistolário jeronimiano, é necessário ressaltar o lugar que o nosso autor reserva para a autoridade do bispo de Roma. Mesmo encontrando-se no Oriente e sob a soberania do episcopado antioqueno, foi para a cátedra petrina que Jerônimo apelou em busca de orientação acerca de como se posicionar na disputa que vivenciava. É possível notar, no texto citado, a completa e total submissão doutrinal e teológica do Estridonense a Roma. Ainda que devamos considerar os elementos retóricos presente nos escritos jeronimianos, não cabe dúvida a intenção de manter a conformidade com as posturas do pontífice romano. Algo que demonstra mais uma vez a forte ligação espiritual e cultural do nosso autor com a Cidade Eterna, que simboliza e sintetiza, para Jerônimo, os ideais da paideia. 
A epístola seguinte à que acabamos de analisar, a de número XVII, endereçada ao presbítero Marco, foi a última escrita em Cálcis e nos indica claramente que Jerônimo não permaneceria por muito mais tempo naquelas paragens:

\begin{abstract}
Jesus é minha testemunha, venerável e Santo Padre, com que gemidos, com que dor te escrevo isso. Muito tempo me calei, será que vou calar para sempre? (BIBLIA DE JERUSALÉM, Isaias XLII,12), diz o Senhor. Não me concedem um lugar no deserto. Diariamente me pedem conta da minha fé, como se houvesse me batizado sem fé. Confesso o que querem e não ficam satisfeitos. Subscrevo suas fórmulas e não acreditam em mim. O único que gostariam é de me ver partir. Em breve irei. Já me arrancaram de parte de minha alma, a meus caríssimos irmãos. Já estou desejando sair daqui: ou melhor, já estou saindo, pois prefiro habitar entre feras do que com cristão desta espécie (Jer., Ep., XVII, 3).
\end{abstract}

A análise do fragmento citado acima, extraído da Epístola XVII, nos permite depreender que, para Jerônimo, a situação em que se encontrava era cada vez mais insustentável. As cobranças dos demais monges com quem compartilha o deserto de Calcis com relação às disputas doutrinais e também de poder em torno do episcopado de Antioquia, assim como a desconfianças dos ascetas em relação à postura de nosso autor, provavelmente por sua vinculação com concepções doutrinais e teológicas do bispo de Roma, marginalizavam ainda mais o Estridonense em relação à comunidade monacal síria.

A saída para essa conjuntura embaraçosa e labiríntica foi para Jerônimo a partida do deserto de Cálcis como ele mesmo anunciou na passagem em análise do seu epistolário. É digno de nota, sempre sem esquecer as estratégias retóricas que o nosso autor utilizava largamente em suas obras, a decepção e o desencanto do Estridonense, que confessava estar com o espírito mutilado por ter de deixar a vida monástica. A questão que podemos nos colocar é até que ponto as atitudes dos ascetas que viviam naquela região da Síria foram um pretexto para que o nosso autor abandonasse um estilo de vida que se revelou bastante diferente do que os sonhos e desejos jeronimianos idealizavam? Em outros termos, a controvérsia em torno do arianismo e da liderança cristã em Antioquia serviram como subterfugio para Jerônimo deixar Cálcis? Responder a uma interrogação dessa monta é sempre uma tarefa bastante complexa e espinhosa. No entanto, é necessário enfrentá-la.

Nossa hipótese é que Jerônimo já se encontrava bastante insatisfeito com as condições vivenciadas no decorrer de sua primeira experiência monástica. As epístolas redigidas nesse período e analisadas no presente texto demonstram esse desagrado e descontentamento, especialmente em virtude da solidão e da rusticidade de seus companheiros de ascetismo. Em outras palavras, o nosso autor esperava encontrar, no deserto de Cálcis, um estilo de vida monástico que aliasse as rigorosas práticas ascéticas e o retiro do seculum e das vicissitudes mundanas com a ênfase no estudo das Escrituras e 
das questões do cristianismo. No entanto, no ermo sírio, o que Jerônimo encontrou foram monges que praticavam uma severa continência, mas que tinham pouca ou nenhuma preocupação com a erudição.

O recrudescimento das controvérsias e disputas em torno do Cisma de Antioquia e as demandas que Jerônimo passou a receber de seus companheiros de ascetismo e solidão indicaram para ele que o deserto de Cálcis não era o seu lugar, não cabendo outra alternativa a ele senão partir. Em suma, as circunstâncias não são um mero pretexto para a retirada, mas consolidam uma ideia, um desejo ou mesmo uma decisão anterior.

O certo é que Jerônimo empreendeu seu êxodo de Cálcis em 377, dirigindo-se primeiramente para o olho do furacão, ou seja, Antioquia, onde permanece na companhia do amigo Evágrio. Em seguida, parte novamente, dessa vez para Constantinopla, onde permanece por três anos antes de voltar para Roma (REBENICH, 2002, p. 10-15). Porém, essas aventuras do Estridonense estão fora do escopo do presente trabalho. O que importa assinalar, nessa oportunidade, é que Jerônimo partiu do deserto de Cálcis, deixando para trás o estilo de vida que considerava o mais adequado e pertinente para que os cristãos atingissem seu objetivo maior, ou seja, a salvação eterna.

\section{Considerações finais}

Nosso objetivo, nesse texto, foi buscar entender, assim como propor, uma explicação para a aparente incongruência entre o discurso de Jerônimo, que enaltecia e exaltava o ideal monástico e a experiência vivida, pois, quando o nosso autor teve a oportunidade de vivenciar esse estilo de vida, conseguiu permanecer apenas três anos no deserto de Cálcis, na Síria. Além disso, buscamos também interpretar esse episódio dentro do universo simbólico das elites da sociedade tarda-antiga articulada pela paideia.

Para compreender e explicar o comportamento do Estridonense, precisamos não esquecer que ele teve uma formação educacional dentro dos parâmetros e moldes da paideia. É verdade que dentro de uma perspectiva cristã, em um momento em que a intelectualidade representante do cristianismo acirrava a disputa com os pensadores pagãos pelo controle e pela herança da paideia, Jerônimo foi um ativo participante desse conflito.

Por outro lado, nosso autor também foi um ardoroso e fervoroso cristão, especialmente um defensor inflamado e entusiasmado da opção de vida monástica que considerava a via perfeita para a salvação. Tanto é assim que incentivava os amigos a se tornarem monges, bem como elogiava e louvava aqueles que adotaram esse estilo de vida. 
Não causa nenhum tipo de surpresa que Jerônimo resolvesse, também ele, compartilhar a melhor forma de existência salvífica. O Estridonense resolveu mergulhar na vida monástica onde essa havia surgido, ou seja, nas regiões desérticas da parcela oriental do Império Romano, mais especificamente no deserto de Cálcis.

Jerônimo vai em busca da salvação por meio da ascese e do retiro do mundo. Porém, a solidão, com o passar do tempo, se transformou em um fardo. Em lugar de um paraíso terrestre, do encontro com Deus, a solidão se revelou mais como o distanciamento do convívio com os amigos e, por conseguintes, das trocas e discussões intelectuais, ou seja, como um afastamento da paideia.

Os companheiros de solidão do Estridonense se revelaram rústicos, bárbaros, a ponto de serem comparado a animais. Isso porque não possuíam o refinamento intelectual, não conheciam os elementos básicos e fundamentais da cultura da elite romana. Afinal de contas, esses homens "perdidos" nos confins desérticos do mundo romano não integravam a elite intelectual do mundo tardo-antigo, estavam inseridos em redes culturais e simbólicas diversas daquelas em que o nosso autor se inseria. Tal situação, se não inviabilizava, dificultava enormemente a assimilação de Jerônimo nesse grupo, criando assim uma tensão que foi aumentando com o passar do tempo.

O ponto de ruptura surge com o recrudescimento das discussões em torno do Cisma de Antioquia. O Estridonense é questionado acerca das suas posturas doutrinais e teológicas. Quando isso acontece, ele se volta para o local que simbolizava tanto a essência de sua formação quanto a essência de sua fé: Roma. A pressão sofrida por Jerônimo consolidou a certeza de que Cálcis não era o seu lugar.

Jerônimo foi um homem marcado pela dualidade, numa época marcada por tensões entre princípios antagônicos, como a continuidade e a ruptura. Por um lado, um intelectual formado dentro de uma tradição de pensamento alicerçada na paideia. Mas também um fervoroso cristão, que entendia o ideal monacal como a forma de vida mais perfeita para os cristãos.

A experiência de Cálcis expõe essa dualidade, assim como anos mais tarde o famoso sonho (CRUZ, 1988, p. 118). A partida de Jerônimo do deserto demonstra que para uma elite intelectual formada nos moldes e parâmetros da paideia, a vida monástica, no estilo oriental, era, senão impossível, no mínimo bastante árdua e penosa. A solução para esse paradoxo, nosso autor encontrou anos mais tarde quando, em Belém, fundou duas comunidades ascéticas urbanas, uma dirigida às mulheres e outra composta por homens, ambas dedicadas ao estudo das Escrituras e das questões teológicas, doutrinais, morais e exegéticas cristãs. O que poderíamos denominar um monacato erudito, uma proposta monástica que aproxima o monge do filósofo. 
O episódio que analisamos e tentamos explicar da vida de Jerônimo não se restringe à individualidade do nosso autor. Ele aponta para problemas mais amplos que concernem às elites intelectuais cristãs da sociedade tardo-romano. Nos permitem pensar e refletir acerca das disputas e conflitos existentes no universo cultural desse momento, percebendo a complexidade e a diversidade da realidade histórica da Antiguidade Tardia.

\section{Referências}

\section{Documentação textual}

JERONIMO. Cartas de San Jeronimo. Introdução, versão e notas por Daniel Ruiz Bueno. Madrid: Biblioteca de Autores Cristianos, 1962.

JERONIMO. De uiris illustribus. Madrid: Gredos, 1985.

\section{Obras de apoio}

ANTIN, P. Essai sur Saint Jérôme. Paris: Letouzey \& Anné, 1951.

BOLLIS, S. Paideía filosófica: o sentido da formação na 'República' de Platão. 2013. Dissertação (Mestrado em Educação) - Programa de Pós-Graduação em Educação da Universidade Federal de Goiás, Goiânia, 2013.

BROWN, P. O fim do mundo clássico: de Marco Aurélio a Maomé. Lisboa: Verbo, 1972.

CANER, D. "Not of This World": the invention of monasticism. In: ROUSSEAU, P. (ed). A companion to Late Antiquity. Oxford: Wiley-Blackwell, 2009, p. 588-600.

CANER, D. Wandering, begging monks: spiritual authority and the promotion of monasticism in Late Antiquity. Berkeley: University of California Press, 2002.

CAVALLERA, F. Saint Jérôme: sa vie et son ouevre. Louvain: Spicilegium Louvaniense, 1922. $2 \mathrm{v}$.

COLUMBAS, G. El monacato primitivo. Madrid: Biblioteca de Autores Cristianos, 1974-75. $2 \mathrm{v}$.

CRUZ, M. A vida monástica nas Cartas de São Jerônimo. Revista do Departamento de História, n. 7, 1988, 116-120.

FINN, R. Asceticism in the Graeco-Roman World. Cambridge: Cambridge University Press, 2009.

FLICHE, A.; MARTIN, V. Histoire de l'Église: de la paix constantiniene à la mort de Théodose. Paris: Bloud \& Gay, 1936.

GEERTZ, C. A interpretação das culturas. Rio de Janeiro: LTC, 1989. 
GOBRY, I. Les moines en Occident: de saint Antoine à saint Basile, les origines orientales. Paris: Fyard, 1985. t. I.

HERTLING, L. Historia de la Iglesia. Barcelona: Herder, 1984.

JAEGER, W. W. Cristianismo primitivo y paideia griega. México: Fondo de Cultura Económica, 1965.

JEDIN, H. Manual de Historia de la Iglesia: la Iglesia imperial después de Constantino hasta finales del siglo VII. Barcelona: Herder, 1980, p.457-465. t. II.

KELLY, J. N. D. Jerome: his life, writings, controversy. London: Duckworth, 1975.

LABRIOLLE, P. De La Paix Constantinienne a la mort de Theodose. Paris: Bloud \& Gay, 1936. v. 3.

LENZENWEGER, J. et al. História da Igreja Católica. São Paulo: Loyola, 2006

MARAVAL, P. Em busca da perfeição: ascetismo e monaquismo. In: CORBIN, A. (org.). História do Cristianismo. São Paulo: Martins Fontes, 2009, p. 97-101.

MARROU, H. I. Decadencia romana o Antiguedad Tardia? Siglo III-VI. Madrid: Rialp, 1980. MASSOLIVER, A. Historia del monacato cristiano: desde los Orígenes hasta san Benito. Madrid: Encuentro, 1994.

MCLYNN, N. Damasus of Rome: a Fourth-Century Pope in context. In: FUHRER, T. (ed.). Rom und Mailand in der Spätantike: RepräsentationenstädtischerRäume in Literatur, Architektur und Kunst. Berlin: de Gruyter, 2012.

MUEHLBERGER, E. Ambivalence about the angelic life: the promise and perils in an early Christian discourse of asceticism. Journal of Early Christian Studies, v. 16, n. 4, p. 447-478, 2008,

PENNA, A. San Jeronimo. Barcelona: Luis Miracle, 1952.

REBENICH, S. Jerome. London: Routledge, 2002.

ROUSSEAU, P. Ascetic, authority and the Church in the age of Jerome and Cassian. Notre Dame: University of Notre Dame Press, 2010.

RUBENSON, S. Asceticism and monasticism, I: Eastern. In: CASIDAY, A.; NORRIS, F. W. (ed). The Cambridge History of Christianity: Constantine to c.600. Cambridge: Cambridge University Press, 2007, p. 637-668.

SAHLINS, M. Ilhas da História. Rio de Janeiro: Jorge Zahar, 1990.

SAUSURRE, F. Curso de Linguística Geral. São Paulo: Cultrix, 1970.

SILVA, G. V. Uma comunidade em estado de alerta: João Crisóstomo e o apoio aos cristãos de Antioquia no combate aos judaizantes. Phoînix, n. 20-2, 2014, p. 129-151.

STEIMANN, J. Saint Jérôme. Paris: du Cerf, 1958.

WIPSZYCKA E. Resources and economic activities of the Egyptian monastic communities (4th-8th century). The Journal of Juristic Papyrology, n. 26, p. 159-263, 2011. 